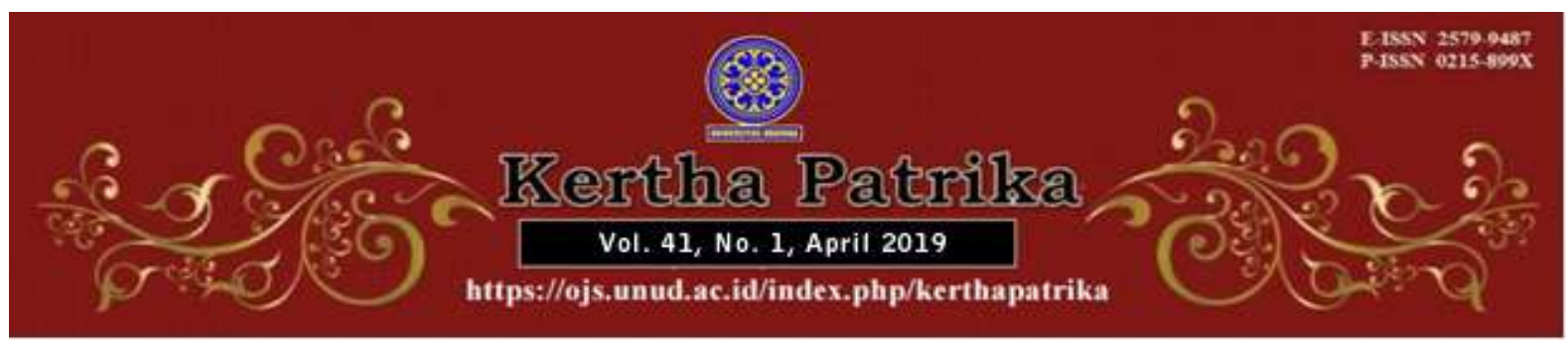

\title{
Gross Violations of Human Rights Veiled within Xinjiang Political Reeducation Camps
}

\author{
Ayu Suci Rakhima, ${ }^{1}$ Ni Gusti Ayu Dyah Satyawati²
}

${ }^{1}$ Faculty of Law Udayana University, E-mail: asuraayusuci@gmail.com ${ }^{2}$ Faculty of Law Udayana University, E-mail: dyah_satyawati@unud.ac.id

\begin{tabular}{l}
\hline Info Artikel \\
\hline Recieved : $26^{\text {th }}$ March 2019 \\
Accepted : $28^{\text {th }}$ April 2019 \\
Published : $30^{\text {th }}$ April 2019 \\
Keywords: \\
Gross Human Rights \\
Violations; Torture; Arbitrary \\
Detention; Responsibility. \\
\\
Corresponding Author: \\
Ayu Suci Rakhima, E-mail: \\
asuraayusuci@gmail.com \\
DOI: \\
10.2484/KP.2019.v41.i01.p01
\end{tabular}

\begin{abstract}
Xinjiang reeducation camps are dedicated to cleanse the practice and existence of religion, and majorly subjects the Uighur moslems. China has constantly denied the conduct of gross human rights violations of Uighur moslems within Xinjiang political reeducation camps. This article will elaborate on the actions done by Xinjiang officials to unveil the gross violations of human rights towards the Uighurs within Xinjiang reeducation camps. The article will also examine the available possibility to criminally hold the perpetrators liable and provide effective relief to the victims. This article is constructed using normative legal research method with statutory, case, and fact approaches, along with conceptual/analytical approach. The result shows that there exist gross violations of human rights towards the Uighurs within Xinjiang reeducation camps in a form of arbitrary detention and torture. Moreover, there are some available possibilities to criminally hold the perpetrators liable and provide effective relief to the victims, namely through a municipal court proceeding and through the Committee against Torture.
\end{abstract}

\section{Introduction}

China's Xinjiang is home to at least 11 million Uighurs and 1.6 Kazakhs. ${ }^{1}$ Ethnical conflict in Xinjiang has been unfolded ever since 2009 through the existence of discriminative actions towards Xinjiang's moslem population, the Uighur. Those actions started with the organized immigration of the Han Chinese to Xinjiang, in which the Hans were prioritized over the Uighurs in terms of employment and economics in Xinjiang. ${ }^{2}$ Since 2016, People's Republic of China (hereinafter, China) has implied repressive policies to the Xinjiang's Uighur by assigning intelligence officials

1 Population by ethnicity, Statistic Bureau of the Xinjiang Uighur Autonomous Region. Available from. http://www.xjtj.gov.cn/sjxc/tjnj-3415-2016xjtjnj/rkjy/201707/t20170714-539451.html (accesed $2^{\text {nd }}$ March 2019)

2 Grose T. A. (2018).The Xinjiang Class: Education, Integration, and the Uyghurs. Journal of Muslim Minority Affairs, 30(1), 97-109. https:// doi.org/10.1080/13602001003650648, p. 100. 
as "adopted" members of civilian families, as well as installing mandatory spyware to conduct surveillance in the area.

The distrust of Chinese governments to the Uighurs has started since the relationship deteriorated in 2009 due to violent riots and a retaliatory crackdown. In 2009, a violent riot broke down in Urumqi, the capital of Uighurs, resulting in the death of nearly 200 Han individuals. ${ }^{3}$ Clashes in the area also occurred in Tiananmen Square in 2013 as well as a violent attack in 2014 in Kunming train station, which resulted in 29 deaths and 100 injuries. ${ }^{4}$ Those riots were supposed to be a form of the rage of the Uighurs towards Chinese's discriminative policy. Instead, it fuels China to restrict the Uighurs very movement and liberty. Aside of that, plenty of Moslem terrorist attacks outside the Xinjiang and China itself contributed to the increasingly heavy restriction on Uighurs' rights of freedoms. ${ }^{5}$

Chinese officials have become dedicated to the concept of "reeducation camps" ever since 2014. ${ }^{6}$ These reeducation camps are institutions established by the Xinjiang officials to conduct political indoctrination through detention and deprivation of freedom of movement towards the Uighurs. ${ }^{7}$ Ironically, Chinese's Consulate for Kazakhstan in February 2018 has denied the existence of such policy empowered practice in Xinjiang, ${ }^{8}$ so did China's Foreign Affairs Ministry in May 2018. ${ }^{9}$ However, as corroborative as the statements of Chinese officials could be, the facts are corroborating their statements in no way. The rapid and constant increase in the number of Uighurs detained in the reeducation camps as of the period of 2015 to 2018.10

China's effort was never intended to physically eradicate the Uighurs, but it was to cleanse them from the so-called contagious ideological disease, Islam. In the view of the government, those who suffer from such disease must be quarantined, and the government's way of achieving such purpose is empowered by the government

${ }^{3}$ Zhang, S., Xu, M., Li, X., Fang, H., Yang, S., \& Liu, J. (2013). Implicit trust between the Uyghur and the Han in Xinjiang, China. PloS one, 8(8), doi:10.1371/journal.pone.0071829.

${ }^{4}$ KilicKanat. Repression in China and Its Consequences in Xinjiang. Available from https://www.hudson.org/research/10480-repression-in-china-and-its-consequences-in-xinjiang. (Accesed25th April 2019)

${ }^{5}$ Kate Cronin-Furman. China Has Chosen Cultural Genocide in Xinjiang - For Now, FP Argument. Available from https://foreignpolicy.com/2018/09/19/china-has-chosen-cultural-genocide-inxinjiang-for-now . (Accesed $11^{\text {st }}$ March 2019)

${ }^{6}$ Adrian Zenz, 2018, New Evidence for China's Political Re-Education Campaign in Xinjiang, China Brief, 18.

${ }^{7}$ HRW Report on China, see generally.

8 AKI Press, Consul of General China Denies Reports on Political Education Camps for Uyghurs in China's Xinjiang. Available fromhttps://akipress.com/news:602025 (Accesed 2nd March 2019)

9 Shih G., China's Mass Indoctrination Camp Evoke Cultural Revolution, Associated Press. Available fromhttps://apnews.com/6e151296fb194f85ba69a8babd972e4d (Accesed2nd March 2019)

${ }^{10}$ Radio Free Asia, Around 120,000 Uyghurs Detained for Re-education in Xinjiang's KashgarPerfecture. Available from https://www.rfa.org/english/news/uyghur/detentions/01222018171657.html (Accesed 2nd March 2019) 
policies in Xinjiang ${ }^{11}$ and practices within the reeducation camp. ${ }^{12}$ In the reeducation camps, the Uighurs are subject to arbitrary detention, torture, and deprivation from their freedom of thoughts and religion. ${ }^{13}$

The practices of China within the reeducation camps in Xinjiang are qualified as crimes against humanity when committed as a part of a widespread or systematic attack directed against any civilian population. ${ }^{14}$ However, there is still minimum evidence to prove the element of 'a widespread or systematic attack against the civilian population', noting that the objects of attack are limited to the Uighurs who practice their religion openly. Moreover, China is not bound by the Rome Statute of the International Criminal Court (hereinafter, Rome Statute), which coveredsuch crime. ${ }^{15}$ Hence, the issue weighs more substantially when assessed from the perspective and legal instruments of human rights, in which China is bound to. China's practices within the reeducation camps in Xinjiang are not in conformity with the provisions under Article 5 and Article 9 of the Universal Declaration of Human Rights (UDHR), Article 7 and Article 9 of the International Covenant on Civil and Political Rights (ICCPR), as well as the Convention against Torture (CAT) in general. ${ }^{16}$ Eventhough China has signed the Covenant on October $5^{\text {th }} 1998$, however has not ratified it. Hence, China is only under obligation to act in good faith and not defeat the purpose of the Covenant. Committing a deprivation of Uighurs' liberty is in fact not in conformity with the purpose of the covenant. Moreover it is important to note that several provisions under the ICCPR were already considered as jus cogens norm and hence, non-derogative. ${ }^{17}$

The conduct of China to Uighurs within the Xinjiang reeducation camps qualifies as gross violations of human rights. ${ }^{18}$ It is based on the fact that those actions were prohibited under the jus cogens norms, which considered fundamental and derogative. The fact that the even European Parliament has paid attention to the issue shows how substantial the issue is in the perspective of human rights. ${ }^{19}$

Regulations of Xinjiang Uygur Autonomous Region on Religious Affairs, 2014 replaced the Regulations of Xinjiang Uygur Autonomous Region on Religious Affairs Management, 1994.

12 HRW Report on China, p.19.

13 HRW Report on China, see generally.

14 Rome Statute ofthe Intenational Criminal Court, Article 7.

15 The State Parties to the Rome Statute, https://asp.icccpi.int/en_menus/asp/states \%20parties/pages/the \%20states $\% 20$ parties $\% 20$ to $\% 20$ the $\% 20$ rom e\%20statute.aspx (Accesed $3^{\text {rd }}$ March 2019)

16 China has ratified the Convention against Torture in 1998.

17 Zenovic P. (2012). Human Rights Enforcement via Peremptory Norms- A Challenge to State Sovereignty, RSGL Research Papers. 6, pp. 31-35.

18 Muhammad FajrinSaragih. (2015)Tinjaua nYuridis Pelanggaran HAM terhadap Muslim Uighur di China Ditinjau dari HukumHumaniter, Fakultas Hukum USU, p. 12.

19 Motion for Resolution: European Parliament resolution on Mass arbitrary detention of Uyghurs and Kazakhs in the Xinjiang Uyghur Autonomous Region (2018/2863(RSP)), http:// www.europarl.europa.eu/doceo/document/B-8-2018-0460_EN.html?redirect (Accesed $2^{\text {nd }}$ March 2019) 
This article is aimed to assess whether or not China's practice within the reeducation camps in Xinjiang qualified as a gross violation of human rights in the perspective of international human rights law. Should the first issue qualifies, this article will also assess the possibility to hold Chinese officials responsible for the gross violations of human rights committed in the reeducation camps towards Uighur.

\section{Method}

This article applies normative legal research method focusing on relevant international legal instruments related to the discussed issue. In approaching the issue, the article uses statutory, case, fact, and conceptual/analytical approaches. The article will be based upon relevant international legal instruments, e.g international conventions, declarations, documents, as well as resolutions adopted by international organization or institutions as the primary legal basis. International court decisions and (State) practices will be used as the secondary legal basis. The materials and sources/resources used in the article will be based upon text books, journals, online websites, as well as news collected through literary study. The article will use descriptive analysis in analyzing the collected legal instruments and sources/resources.

\section{Result and Analysis}

\subsection{Gross Human Rights Violations towards the Uighurs within the Reeducation Camps in Xinjiang \\ 3.1.1. Arbitrary Detention}

The prohibition of arbitrary detention is governed under Article 9 of the UDHR and Article 9(1) of the ICCPR. It has also been widely considered as a crime by numerous States, including China alone in Article 37 of its Constitution. ${ }^{20}$ The United Nations has emphasized in the Tehrancase ${ }^{21}$ judgement that the prohibition of arbitrary detention shall be recognized as a customary international law and a part of jus cogens norm..$^{22}$ Consequently, despite the fact that China is not bound by the ICCPR, China is bound by the prohibition of arbitrary detention under customary of international law and jus cogens norms. The concrete provision of such prohibition can be found in the ICCPR and reads as follow: "Everyone has the right to liberty and security of person. No one shall be subjected to arbitrary arrest or detention. No one shall be deprived of his liberty except on such grounds and in accordance with such procedure as are established by law." 23

20 UN Working Group on Arbitrary Detention, Deliberation No 9 Concerning the Definition and Scope of Arbitrary Deprivation of Liberty under Customary International Law in UN Human Rights Council, 'Report of the Working Group on Arbitrary Detention', A/HRC/22/44, 24 December 2012, p. $43,46$.

21 United States Diplomatic and Consular Staff in Tehran (United States of America v. Iran), Judgments, I.C.J. Reports 1980, p. 42, 91.

22 UN Working Group on Arbitrary Detention, Deliberation No 9 Concerning the Definition and Scope of Arbitrary Deprivation of Liberty under Customary International Law in UN Human Rights Council, 'Report of the Working Group on Arbitrary Detention', A/HRC/22/44, 24 December 2012, p. 51.

23 International Covenant on Civil and Political Rights, Article 9 (1). 
Under the article, the deprivation of liberty in a form of arrest or detention is justified, so far that it is not arbitrary. Arbitrariness goes beyond a mere "unlawfulness" of an arrest or detention.

The practice in the case of Gorji-Dinka v. Cameroon ${ }^{24}$ and Van Alphen v. Netherlands, ${ }^{25}$ assessment to arbitrariness includes the elements of inappropriateness, injustice, as well as unreasonableness, necessity and proportionality. ${ }^{26}$ The absence of a legal basis to detain a person is not substantial to prove that such detention is arbitrary. Detention may be legally permitted under the municipal law of a state, but qualifies as arbitrary detention due to the absence of adequate explanation and the lack of periodical re-evaluation ${ }^{27}$ as to the justification of continuance detention. ${ }^{28}$ Moreover, detention on the basis of persons practicing their rights under the ICCPR, including the rights to religion (Article 18 ICCPR), qualifies as an arbitrary detention. ${ }^{29}$

To consider whether or not arbitrary detention has been committed in the present issue, it is necessary to assess the practice of detention in the reeducation camps in Xinjiang to the applicable qualifications of arbitrary detention, as infra:

The first and foremost assessment lies on the legal basis of the detention in Xinjiang reeducation center, followed by the background of such practice. The applicable Regulations in Xinjiang indeed ban the mere practice and appearance of religion, prohibit the teaching of religions to children by teachers or parents, to the extent where any "hint of religion" in education is eliminated. ${ }^{30}$ These overly broad prohibitions allowed the possibility to criminalize the Uighur moslems by merely and peacefully practicing their beliefs. ${ }^{31}$ Even if there is no explicit regulations within Xinjiang that authorize the deprivation of the Uighurs' liberty by detaining them, there is a hint of 'educational placement' that may be the basis of the whole reeducation camps operations. The rule of educational placement is governed under CCPR/C/GC/35, p. 12.

27 1189/2003, Fernando v. Sri Lanka, p. 9.2; 1373/2005, Dissanakye v. Sri Lanka, p. 8.3.

28 1324/2004, Shafiq v. Australia, p. 7.2.

29 General Comment no. 35, Article 9 (Liberty and Security of Person), 16 December 2014, CCPR/C/GC/35, p. 17.

$30 \quad$ Xinjiang Regulations on Religious Affairs 2014.

31 Adhe Nuansa Wibisono, (2015.) Strategi Kontra-Terorisme Pemerintah Tiongkok dalam Merespon Gerakan Bersenjata Uighur di Wilayah Xinjiang, Universitas Indonesia, p. 4; Marika Vicziany, State Responses to Islamic Terrorism in Western China and Their Impact on South Asia, Contemporary South Asia, Vol. 12, No. 2 (2003), pp. 243-262; Susan Trevaskes, Severe and Swift Justice in China, British Journal of Criminology, Vol. 47 (2007), pp. 23-41; Michael Clarke, 2010, Widening the Net: China's Anti-Terror Laws and Human Rights in the Xinjiang Uyghur Autonomous Region, The International Journal of Human Rights, Vol. 14, p. 20. 
Article 30 of Counter-Terrorism Law of the People's Republic of China ${ }^{32}$ along with Article $41-43$ of its implementation measures for Xinjiang. ${ }^{33}$ The provision of educational placement provides the potentially indefinite detention. Even though its application is limited, violations related to the suspicions for terrorism, which includes the practice of religion, falls within the imposing of the prison-like educational centers with no certainty of the period of detention. Assuming that those regulations are considered to be the legal basis to impose sanctions in a form of reeducation to the Uighurs, does that mean that the detention is lawful?

International human rights legal instruments indicate thatthe detention in Xinjiang reeducation camps are still considered unlawful and arbitrary. The detention of Uighurs in Xinjiang reeducation camp is relying upon the criminalization of the Uighurs for practicing their religion and beliefs. Should there be the basis to criminalize the Uighurs for their belief, such provision alone is a violation ofthe recognition and protection of the rights to religion as a fundamental right. Moreover, detention on the basis of depriving persons from their rights to religion qualifies as arbitrary detention and hence, violates the provision of the rights to liberty and security of persons as regulated under Article 9 of the ICCPR.

\subsubsection{Torture}

Subjecting persons to torture or cruel, inhuman, degrading treatment is widely and uniformly prohibited under international human rights instruments, such as the $\mathrm{UDHR}^{34}$ and its covenant, the ICCPR. ${ }^{35}$ Not only under treaty law, in accordance to Furundzija judgement, ${ }^{36}$ prohibition of torture is also considered as jus cogens norm. Consequently, violations towards it is considered as gross violations of human rights, noting that such norms are fundamental and non-derogative. ${ }^{37}$ Torture, specifically, is the most reprehensible act among all the three prohibited conduct under Article 7 of the ICCPR. ${ }^{38}$ Moreover, the 1987 Convention against Torture and Other Cruel, Inhuman, Degrading Treatment or Punishment (CAT) defines torture under its Article 1 as follows:

"[...] the term "torture" means any act by which severe pain or suffering, whether physical or mental, is intentionally inflicted on a person for such purposes as obtaining from him or a third person information or a confession, punishing him for an act he or a third person, or for any reason based on

Counter-Terrorism Law of the People's Republic of China (translated version), Retrieved fromhttps:/ / www.chinalawtranslate.com/en/\%E5\%8F\%8D\%E6\%81\%90\%E6\%80\%96\%E4\%B8 \%BB\%E4\%B9\%89\%E6\%B3\%95-\%EF\%BC\%882015\%EF\%BC\%89/ (Accesed 3rd March 2019)

33 Jeremy Daum, XJ Education Centers Exist, but DoesTheir LegalBasis?, China Law Translate, August 14 2018. https://www.chinalawtranslate.com/xj-education-centers-exist-but-doestheir-legal-basis/?lang=en\#_ednref7 (Accesed $3^{\text {rd }}$ March 2019)

34 Universal Declaration of Human Rights, Art. 5.

35 International Covenant on Civil and Political Rights, Art. 7.

36 IT-95-17/1-T, Prosecutor v. Furundzija, p. 155-157.

37 Zenovic P. (2012) Human rights enforcement via peremptory norms- a challenge to state sovereignty, RSGL Research Papers No. 6, pp. 31-35.

38 Manfred Nowak, 1993, UN Covenant on Civil and Political Rights: CCPR Commentary, NP Engel, p. 129. 
discrimination of any kind, when such pain or suffering is inflicted by or at the instigation of or with the consent or acquiescence of a public official or other person action in an official capacity. It does not include pain or suffering arising only from, inherent in or incidental to lawful sanctions." 39

To determine whether or not there was the commission of torture or other cruel, inhuman, degrading treatment towards the Uighurs in Xinjiang reeducation center, it is essential to assess it element by element, as infra:

Firstly, whether or not there was an intentional infliction of severe pain or suffering, whether physical or mental, on person or persons. ${ }^{40}$ The essential threshold of the first element is the severity of the pain or suffering inflicted. Although inhuman treatment during detention most likely considered as tortured due to the powerlessness of the victim, ${ }^{41}$ the element of severity still needs to be proven. To meet the requirement of severity, the infliction of pain or suffering is not limited to the act of commission, but also omission. When omitted, prolonged suffocation, ${ }^{42}$ solitary confinement, ${ }^{43}$ as well as denial of rest or sleep, ${ }^{44}$ food $^{45}$ and water, ${ }^{46}$ qualified as severe infliction of pain or suffering. Moreover, acts of commission which qualified as severe infliction include prolonged handcuffing or deprivation of movement, ${ }^{47}$ as well as nails removal. ${ }^{48}$

In the current issue, the inflictions of severe pain or suffering are proven to be conducted towards the Uighurs in the Xinjiang reeducation camps. Prior to the detention, the Uighurs are tied on a metal chair known as the "tiger chair" for days to intentionally paralyze them and prevent them from moving. Afterwards, they will be preceded to an interrogation room where they will be tortured and forced to confess their "crime" of belief. ${ }^{49}$ During that time as well, they will not be receiving any food or water. 50 To force the Uighurs to confess their "crime" of belief, "tiger chair" is not the only method that the officials are using. The Uighurs are sometimes hung overnight or even chained on a metal bed. Moreover, they were held individually in a room of $2 \times 2$ meters with no ventilation, and no outside access neither to the family,

39 Convention against Torture and Other Cruel, Inhuman, Degrading Treatment or Punishment, Art. 1; Sarah Joseph, et al., 2005, The Intenational Covenant on Civil and Political Rights: Cases, Materials, and Commentary Second Edition, Oxford University Press, p. 195-196.

40 Chitimira, H, \&Mokone, P. (2017). A General Legislative Analysis of "Torture" as a Human Rights Violation in Zimbabwe. PER: PotchefstroomseElektronieseRegsblad, 20(1).

41 Manfred Nowak and Elizabeth McArthur, 2005, The United Nations Convention Against Torture: A Commentary, Oxford University Press, p. 77.

42 Prosecutor v. ZejnilDelalić et al., IT-96-21-T, p. 467.

43 General Comment No. 20: Article 7 (Prohibition of Torture, or Other Cruel, Inhuman, Degrading Treatment or Punishment, 10 March 1992, p. 6.

44 Prosecutor v. DraganNicolic, IT-94-2-T, p. 198.

45 Prosecutor v. Hadzihansananovic, IT-01-47-T, paras. 1191, 1681.

46 Malawi African Association and Others v. Mauritania, p. 12.

47 Committee against Torture, Concluding Observations on USA, UN Doc. CAT/C.USA/CO/2, p. 24.

48 Prosecutor v. André Ntagerura et al., ICTR-99-46-T.

49 HRW Report on China, p.33.

50 HRW Report on China, p.34. 
government, or their fellow detainee. ${ }^{51}$ Their detention condition does not only qualify as prolonged suffocation, but also as solitary confinement, a concept of detention that has been widely condemnedin international human rights and international humanitarian law. Providing the fact that each and every condition in Xinjiang reeducation camps qualifies as a form of severe infliction of pain or suffering, hence the first element is fulfilled.

Secondly, the intention to inflict severe pain or suffering as supra is intended to achieve a specified purpose. The mere infliction of severe pain or suffering with no intended purpose to achieve falls outside the criteria of torture, same goes to the 'negligence' with no intended purposes. ${ }^{52}$ The purpose that motivated the infliction of severe pain or suffering in the first place is the essential element of torture. To discriminate a certain group of people qualifies as one of the purposes that may render an infliction of severe pain or suffering as torture, just as practiced in the case of Delalic. ${ }^{53}$ In the current issue, the sole purpose of the infliction of severe pain or suffering towards the Uighurs is to "cleanse", "fix", "reeducate" and "heal" the Uighurs from their belief or religion, which China considers as a crime or even as a disease. ${ }^{54}$ Not to mention that they are forced to study the Han language, to sing praising songs for China, as well as to glorify China alongside with the President. 55 The infliction of severe pain or suffering is intended to achieve the condition in which the Uighur is "skinned" and pulled apart from their belief, which does not only serve as a mere form of discrimination but also a deprivation from the rights to religion. Coming to the conclusion that the infliction of severe pain or suffering was intended to achieve a designated purpose, hence the third element is satisfied.

Thirdly, the conduct must be carried out under official capacity. The element under the Article 1 of the CAT as supra stipulates that it requires public officials involvement in order to render the act as torture. ${ }^{56}$ The term "public officials" is still considered too narrow to qualify the existence of official capacity. Accordingly, the Committee Against Torture recognizes "a person acting in an official capacity" as de facto authorities holding the comparable governmental authority. However such issue may not be substantial to the current issue in question, noting that the involvements of Chinese public officials are most likely proven at this point. Aside of the fact that the practice of reeducation camp in Xinjiang is legislatively empowered, the commission which was done by Xinjiang's officials (both police and/or military) are substantial to prove the involvement of Chinese government in the practice of torture towards Uighurs in the Xinjiang reeducation camps.

$51 \quad$ Ibid.

52 J.Herman Burgers and H. Danelius, 1988, The United Nations Convention against Torture, MartinusNijhoff, p. 118.

53 Prosecutor v. ZejnilDelalić et al., IT-96-21-T, p. 470.

54 Speech of the Ili Communist Party Secretary, Xinjiang, October 2017, as cited in HRW Report on China, p. 35.

55 Adrian Zenz. (2018). New Evidence for China's Political Re-education Campaign in Xinjiang.China Brief, 18.

56 R. McCorquodale and R. La Forgia. (2001)Taking off the Blindfolds: Torture by non-State Actors, Human Rights Law Review 189, p. 205-211. 
As the elements of torture are satisfied, it can be concluded that there exists the commission of torture towards the Uighurs in the Xinjiang reeducation camp. In this case, China has failed to take effective legislative, administrative, judicial or other measures to prevent the act of torture, hence violated Article 2 of the CAT. ${ }^{57}$ The fact that the act of torture in Chinese territory was carried out by its official shows that Chinese government has also failed to prevent its public officials to constitute the act of torture as governed in Article 16 of the CAT. 58

The question on whether the act of torture, in this case, can be considered as a crime against humanity may arise. However, to consider whether or not torture in the case at hand qualifies as a crime against humanity under Article 7(1)(f) of the Rome Statute, the element of "widespread or systematic attack against civilian population" is still necessary to be proven. However, no evidence so far showing that the action towards Uighur is a "widespread or systematic attack against civilian populations". The action cannot also qualify as the crime of genocide due to the absence of massacre and intention of China to destroy the Uighur group, noting that they are only destroying the Uighurs' belief through non-physical actions. Therefore, the torturing of the Uighurs in Xinjiang reeducation camp qualifies as a violation of human rights under Article 7 of ICCPR, and other relevant human rights instruments prohibiting torture.

Therefore it can be concluded that indeed the act of arbitrary detention and torture occurred in Xinjiang. The commission of both actions are considered as gross violations of human rights noting that both prohibitions of arbitrary detention ${ }^{59}$ and torture $^{60}$ are considered as jus cogens norms. The violation against those prohibitions is considered as gross violation of human rights noting that the norms under jus cogens are fundamental and non-derogative. ${ }^{61}$

\subsection{Possibility to Seek for Criminal Responsibility of the Perpetrators and Proper Relief for the Victims}

\subsubsection{Before China's Municipal Court}

China is under an international obligation to take any necessary measure to settle any gross violation of human rights within its jurisdiction. ${ }^{62}$ Article 2 of the ICCPR imposed the obligation for China to ensure that the rights under the Covenant areprotected and recognized under its municipal legislation. ${ }^{63}$ Moreover, Article 3 of

57 Convention against Torture, Article 2.

58 Convention against Torture, Article 16.

59 UN Working Group on Arbitrary Detention, Deliberation No 9 Concerning the Definition and Scope of Arbitrary Deprivation of Liberty under Customary International Law in UN Human Rights Council, 'Report of the Working Group on Arbitrary Detention', A/HRC/22/44, 24 December 2012, p. 51.

60 IT-95-17/1-T, Prosecutor v. Furundzija, pp. 155-157.

61 Zenovic P. (2012) Human Rights Enforcement via Peremptory Norms- a Challenge to State Sovereignty, RSGL Research Papers. 6, pp. 31-35.

62 Rhona K. M. Smith. (2010)Texts and Materials on International Human Rights Second Edition, Routledge, p. 211; Dugard J, 1982, The Application of Customary International Law Affecting Human Rights by National Tribunal, Cambridge University Press. 76, p. 248.

63 International Covenant on Civil and Political Rights, Article 2. 
the ICCPR imposes an obligation for a State to provide an effective remedy ${ }^{64}$ for person or persons whose rights under the Covenant had been violated. ${ }^{5}$ Hence, China is under obligation to firstly, govern that the conduct of arbitrary detention and torture are considered as a crime under its municipal law. Secondly impose criminal liability against its officials who had acted not in conformity with the recognition and protection of human rights. Thirdly , provide an adequate and proper remedy for persons whose human rights had been violated. The judicial remedy in a form of imposing criminal liability against the officials who had constitute the violation is considered essential noting that the violation in the current issue is relating to torture, which is a grave breach of human rights. ${ }^{66}$

With respect to China's obligation under the relevant international human rights instruments, Chinese municipal legislation serves as an option to settle the matter of gross human rights violation in the Xinjiang reeducation camp. Hence, it is the first option to seek for liability for the gross violation of human rights towards the Uighurs within the Xinjiang reeducation camp is to rely upon Chinese municipal provisions and its municipal court.

However, concerns may arise that the exercise of the remedy under the municipal court would not give effect to the victims of human rights violation and may not be effective to hold the perpetrator liable. In case of the municipal exercise is prolonged or unlikely to bring the effect of relief to the victim of human rights violation, which is the case in the Chinese municipal institutions, ${ }^{67}$ another option is open to settle the case beforethe Committee against Torture or the Human Rights Committee. It is important to note that it is still necessary to exhaust the municipal exercise prior to the escalated proceeding before any international human rights Committee.

\subsubsection{Before the Committee against Torture}

The principle of universal jurisdiction is recognized by the Committee against Torture to oblige states to take into custody and prosecute the perpetrator of torture or other cruel, inhuman, degrading treatment. ${ }^{68}$ The Committee against Torture possesses several competencies to ensure the promotion and recognition of human rights. However, it is important to note that a State may refuse to recognize its competence through reservations, as governed under Article 21 of the CAT. China has made such reservation and refused to recognize the Committee's competence under Article 20 of

A. ConcadoTrindade, 1983, The Application of the Rule of Exhaustion of Local Remedies in International Law: its Rationale in the International Protection of Individual Rights, Cambridge University Press, p. 58.

65 International Covenant on Civil and Political Rights, Article 2.

66 Communication 612/95, Vicente et al. v. Colombia.

67 M. Rayila.(2011)The Pain of a Nation: The Invisibility of Uyghurs in China Proper.The Equal Rights Review. 6, p. 51.

68 Manfred Nowak.(2002).,Introduction to The International Human Rights Regime.Brill Academy Publisher. p. 291-292. 
the CAT. ${ }^{69}$ This Article stipulates the Committee's competence to seek for co-operation to a related State Party in case the Committee received reliable information which appears to contain a well-founded indication that torture is being systematically practiced in the territory of a State Party. ${ }^{70}$ However, China still recognizes the competence of the Committee under Article 22 that entitled the Committee to consider any communication submitted to it. In that case, it is possible for individuals to submit communication to the Committee against Torture as has been practiced in the case of Ntahiraja v. Burundi, ${ }^{71}$ Ramirez v. Mexico, ${ }^{72}$ Gahungu v. Burundi, ${ }^{73}$ and other precedents. Individuals may submit its complaint relating to the violation of human rights with the following requirements:

a. The same matter has not been, and is not being, examined under another procedure of international investigation or settlement;

b. The individuals haveexhausted all available domestic remedies; this shall not be the rule when the application of the remedies is unreasonably prolonged or is unlikely to bring effective relief to the person who is the victim of the violation. ${ }^{74}$

In the current issue, it is possible for the Uighurs, who had been the victim of the gross violation of human rights in the Xinjiang reeducation camps, to submit their claim to the Committee against Torture as an individual. It is, however, only possible when the certain exhaustion for national remedies has been taken in advance. In that case, noting that China has not fulfilled its obligation to provide adequate and effective municipal remedies for the victims of the human rights violations, it is possible for the victims to submit their claims to the Committee against Torture. In fact, the nonexhaustion of local remedies is a common procedural issue before the Committee. In the judgment of Ramirez v. Mexico, the national Court has not properly settled the claims by the victims and even labeled the claim as "without substance". ${ }^{75}$ The Committee against Torture then includes "non-exhaustion of local remedies" as the procedural issue of the case. However, the Committee's ruling towards the case was clear that the conduct qualifies as a violation of human rights. ${ }^{76}$ Moreover, the Committee also ruled that Mexico is under obligation to release the victims from detention, provide full reparation towards the victim, punish the perpetrators, as well as to revise its legislation that is not in conformity with the protection of human rights. ${ }^{77}$

The practice of submitting the claim individually to the Committee against torture may be the most hopeful option to seek for justice in the current issue. Hence, it is

69 Parties, Objections, and Reservation to the Convention against Torture. https://treaties.un.org/pages/ViewDetails.aspx?src=IND\&mtdsg_no=IV9\&chapter $=4 \&$ lang $=$ en $\left(\right.$ Accessed $17^{\text {th }}$ March 2019)

70 Convention against Torture, Article 20.

71 Communication No. 575/2013, Ntahiraja v. Burundi.

72 Communication No. 500/2012, Ramirez v. Mexico.

73 Communication No. 522/2012, Gahungu v. Burundi.

74 Convention against Torture, Article 22(4).

75 Communication No. 500/2012, Ramirezv. Mexico, p. 2.18.

76 Communication No. 500/2012, Ramirezv. Mexico, p. 18.

77 Communication No. 500/2012, Ramirez v. Mexico, p. 19. 
possible for The Uighurs to submit its claim non-anonymously to the Committee against Torture despite the non-exhaustion of local remedies from China.

\section{Conclusion}

Assessing from the applicable provisions in international law related to human rights, the detention of Uighurs in the Xinjiang reeducation Camps by China is subject to gross violations of human rights. The gross violation of human rights identified within the Xinjiang reeducation camps are so far arbitrary detention and torture. Both considered as gross violations of human rights noting the fact that the prohibition against arbitrary detention and torture constitute a jus cogens norm, the fundamental and non-derogative norms under international law.

The arrest of the Uighurs which was implicitly authorized by the local policy alone has constituted an unlawful basis of arrest, hence amounts to arbitrary detention. Moreover, numerous treatments towards the Uighur in the Xinjiang reeducation camps during the period of their detention has inflicted severe mental or physical pain or suffering towards them. The treatments were done with the official capacity and aimed to achieve a designated purpose of discrimination. Hence, it falls beyond the definition of cruel, inhuman and degrading treatment as it qualifies in a narrower threshold of torture.

To call out the responsibility of the gross violation of human rights within the reeducation camps in Xinjiang, there are several possible ways. First is to call out China's obligation under the ICCPR to examine the issue under its national court. Second is to submit the claim to the Committee against Torture under the Human Rights Committee. Hence, despite the unimaginable cruelty within the reeducation camps, there is still a way out to provide relief to the victims of such gross human rights violations.

\section{REFERENCES}

\section{$\underline{\text { Books }}$}

Burgers J. \&Danelius H. (1988). The United Nations Convention against Torture. Leiden. The Netherlands: Brill Academy Publisher.

Joseph S., et al. (2005) TheInternational Covenant on Civil and Political Rights: Cases, Materials, and Commentary Second Edition. Oxford. UK: Oxford University Press.

Nowak, M. (1993). UN Covenant on Civil and Political Rights: CCPR Commentary. Strasbourg. Germany: NP Engel.

Nowak, M. (2002), Introduction to The International Human Rights Regime. Leiden. The Netherlands: Brill Academy Publisher. 
Manfred Nowak and Elizabeth McArthur, (2005), The United Nations Convention Against Torture: A Commentary, Oxford: Oxford University Press

Smith R. (2010). Texts and Materials on International Human Rights Second Edition. Abingdon-on-Thames. UK: Routledge.

Trindade, C. (1983). The Application of the Rule of Exhaustion of Local Remedies in International Law: its Rationale in the International Protection of Individual Rights. England. UK: Cambridge University Press.

Wibisono A. (2015). Strategi Kontra-Terorisme Pemerintah Tiongkok dalam Merespon Gerakan Bersenjata Uighur di Wilayah Xinjiang. Depok. Indonesia: Universitas Indonesia.

\section{Journals}

Chitimira, H, \&Mokone, P. (2017). A General Legislative Analysis of "Torture" as a Human Rights Violation in Zimbabwe. PER: Potchefstroomse Elektroniese Regsblad, 20(1), 1-41, 10.17159/1727-3781/2017/v20i0a1271.

Clarke M. (2010). Widening the Net: China's Anti-Terror Laws and Human Rights in the Xinjiang Uyghur Autonomous Region. The International Journal of Human Rights, 14(1), 542-554, doi: 10.1080/13642980802710855.

Dugard J, 1982, The Application of Customary International Law Affecting Human Rights by National Tribunal, American Society of International Law, 76, 245-251,doi: 10.1017/S0272503700030755.

Grose T. A., The Xinjiang Class: Education, Integration, and the Uyghurs, Journal of Muslim Minority Affairs, 30(1), 97-109, doi: 10.1017/S1468109915000377.

M. Rayila. (2011). The Pain of a Nation: The Invisibility of Uyghurs in China Proper. The Equal Rights Review, Vol. 6.

McCorquodale R. \& La Forgia R. (2001). Taking off the Blindfolds: Torture by non-State Actors. Human Rights Law Review, Vol. 189.

Saragih M. F. (2016). Tinjauan Yuridis Pelanggaran HAM terhadap Muslim Uighur di China Ditinjau dari Hukum Humaniter. Jurnal Fakultas Hukum USU, 4(2).

Trevaskes S. (2007) Severe and Swift Justice in China. British Journal of Criminology, 47(1), 23-41, doi: 10.1093/bjc/azl085.

Vicziany M. (2003). State Responses to Islamic Terrorism in Western China and Their Impact on South Asia. Contemporary South Asia, 12(2), 243-262, doi: 10.1080/095849302000147690. 
Zenovic P., 2012, Human Rights Enforcement via Peremptory Norms- A Challenge to State Sovereignty, RSGL Research Papers No. 6

Zenz A. (2018). 'Thoroughly Reforming Them Towards a Healthy Heart Attitude': China's Political Re-Education Campaign in Xinjiang. Central Asian Survey, 38(1), 102129, doi: 10.1080/02634937.2018.1507997.

Zhang, S., Xu, M., Li, X., Fang, H., Yang, S., \& Liu, J. (2013). Implicit Trust between the Uyghur and the Han in Xinjiang, China. PloS one, 8(8), doi:10.1371/journal.pone.0071829.

\section{International Instruments}

Covention against Torture and Other Cruel, Inhuman, Degrading Treatment or Punishment.

General Comment No. 20: Article 7 (Prohibition of Torture, or Other Cruel, Inhuman, Degrading Treatment or Punishment, 10 March 1992.

General Comment No. 35, Article 9 (Liberty and Security of Person), 16 December 2014, CCPR/C/GC/35.

International Covenant on Civil and Political Rights.

Motion for Resolution: European Parliament resolution on Mass arbitrary detention of Uyghurs and Kazakhs in the Xinjiang Uyghur Autonomous Region (2018/2863(RSP)). Retrieved from http://www.europarl.europa.eu/doceo/document/B-8-20180460_EN.html?redirect (accessed on 22/03/19)

Rome Statute on the International Criminal Court.

Universal Declaration of Human Rights.

\section{International Reports}

Human Rights Watch, "Eradication Ideological Viruses" China's Campaign of Repression Against Xinjiang's Muslim, September 2018.

\section{Case Law}

Communication 612/95, Vicente et al. v. Colombia.

Communication No. 1134/2002, Gorji-Dinka v. Cameroon.

Communication No. 1189/2003, Fernando v. Sri Lanka.

Communication No. 1324/2005, Shafiq v. Australia.

Communication No. 1373/2005, Dissanakye v. Sri Lanka.

Communication No. 305/1988, Van Alphen v. Netherlands. 
Communication No. 500/2012, Ramirez v. Mexico.

Communication No. 522/2012, Gahungu v. Burundi.

Communication No. 575/2013, Ntahiraja v. Burundi.

Malawi African Association and Others v. Mauritania.

Prosecutor v. André Ntagerura et al., ICTR-99-46-T.

Prosecutor v. DraganNicolic, IT-94-2-T.

Prosecutor v. Furundzija, IT-95-17/1-T.

Prosecutor v. Hadzihansananovic, IT-01-47-T.

Prosecutor v. ZejnilDelalić et al., IT-96-21-T.

United States Diplomatic and Consular Staff in Tehran (United States of America v. Iran), Judgments, I.C.J. Reports 1980, p.42.

\section{National Legal Instruments}

Counter-Terrorism Law of the People's Republic of China.

Regulations of Xinjiang Uygur Autonomous Region on Religious Affairs, 2014

Regulations of Xinjiang Uygur Autonomous Region on Religious Affairs Management, 1994.

\section{United Nations Documents}

Committee against Torture, Concluding Observations on USA, UN Doc.

CAT/C.USA/CO/2.

UN Working Group on Arbitrary Detention, Deliberation No 9 Concerning the Definition and Scope of Arbitrary Deprivation of Liberty under Customary International Law in UN Human Rights Council, 'Report of the Working Group on Arbitrary Detention', A/HRC/22/44, 24 December 2012.

\section{Internet}

AKI Press. (2018 February 7). Consul of General China Denies Reports on Political Education Camps for Uyghurs in China's Xinjiang. Retrieved from https://akipress.com/news:602025 (accessed on 02/03/19)

Cronin-Furman K. (2018). China Has Chosen Cultural Genocide in Xinjiang - For Now, FP Argument. Retrieved from https://foreignpolicy.com/2018/09/19/china-has-chosencultural-genocide-in-xinjiang-for-now (accessed on 01/03/19)

Daum J. (2018 August 14). XJ Education Centers Exist, but does their legal basis?, China Law Translate. Retrieved from https://www.chinalawtranslate.com/xj-educationcenters-exist-but-does-their-legal-basis/?lang=en\#_ednref7 (accessed on 3/03/19) 
KilicKanat. (2014). Repression in China and Its Consequences in Xinjiang. Retreived from https://www.hudson.org/research/10480-repression-in-china-and-its-consequencesin-xinjiang (accessed on 25/4/19)

Parties, Objections, and Reservation to the Convention against Torture. Retrieved from https://treaties.un.org/pages/ViewDetails.aspx?src=IND\&mtdsg_no=IV-

9\&chapter $=4 \&$ lang $=$ en $\quad$ (accessed on 17/03/2019)

Population by ethnicity, Statistic Bureau of the Xinjiang Uighur Autonomous Region, March 15, 2017. Retrieved from http://www.xjtj.gov.cn/sjxc/tjnj-34152016xjtjnj/rkjy/201707/t20170714-539451.html (accessed on 02/03/2019)

Radio Free Asia. (2018 January 22). Around 120,000 Uyghurs Detained for Re-education in Xinjiang's KashgarPerfecture. $\quad$ Retrieved from https://www.rfa.org/english/news/uyghur/detentions/01222018171657.html (accessed on 02/03/19)

Shih G. (2018 May) China's Mass Indoctrination Camp Evoke Cultural Revolution, Associated Press. Retrieved from https://apnews.com/6e151296fb194f85ba69a8babd972e4d (accessed on 02/03/19)

The State Parties to the Rome Statute. Retrieved from https://asp.icccpi.int/en_menus/asp/states $\% 20$ parties/pages/the $\% 20$ states $\% 20$ parties $\% 20$ to $\% 20$ the \%20rome\%20statute.aspx (accessed on 3/03/19) 